\title{
PENANGANAN SAMPAH ORGANIK DENGAN BAK SAMPAH KOMPOSTER DI DUSUN SUSUKAN KELURAHAN SUSUKAN KECAMATAN SUSUKAN KABUPATEN SEMARANG
}

\author{
Nur Aklis, dan Masyrukan \\ Prodi Teknik Mesin - Fakultas Teknik, \\ Universitas Muhammadiyah Surakarta \\ Nur.Aklis@ums.ac.id \\ masyrukan@ums.ac.id
}

\begin{abstract}
Not properly managed of garbage will impact the health, social and economic. It occurs in RT 03, RT 04 RW 1, Susukan Village, Semarang District. Most residents of both RT are still throwing garbage in any place, and others make puddles for landfills. This paper addresses the issue of handling organic waste from the initially discarded in places and wallow carelessly processed into compost and liquid fertilizer in a composter in Susukan Village, District of Semarang. The activities begins with making management team that are divided according to their respective RT, provision of trash for inorganic waste, manufacture and operation of the composter training for the management team, training provision and operation of the composter for residents. The results of activities undertaken resident of RT 03 RW 04 has a system to manage garbage, produce fertilizer so the impact on improving the quality of health and social citizens.
\end{abstract}

Kata kunci: garbage separator, composter, compost, liquid fertilizer

\section{PENDAHULUAN}

Sampah sudah menjadi masalah umum yang dialami masyarakat. Kebanyakan masyarakat masih memahami sampah sebagai barang yang tidak diinginkan sehingga harus segera dibuang. Persepsi masyarakat mengenai sampah inilah yang menjadikan sampah hanya berpindah tempat dan akhirnya menumpuk pada satu tempat saja, misalnya tempat pembuangan akhir (TPA). Apabila sampah tidak dikelola dengan baik maka akan berdampak pada masalah kesehatan berupa timbulnya penyakit diare, typus, kolera demam berdarah dan penyakit lainnya. Pembuangan sampah di tempat yang tidak semestinya juga bisa mengakibatkan persoalan sosial bahkan lebih jauh lagi bisa berdampak pada masalah ekonomi. Misalkan sampah yang dibuang disungai bisa mengakibatkan banjir yang sangat merugikan dalam segi ekonomi.

Banyak cara telah diusahan oleh manusia untuk menyelesaikan persoalan sampah baik melalui pendekatan sosial maupun pada pendekatan teknologi. Pendekatan sosial dilakukan dengan menumbuhkan kesadaran masyarakat untuk membuang sampah pada tempatnya dan pembuatan sistem pengelolaan sampah, sedangkan pada pendekatan teknologi adalah 
usaha yang dilakukan dengan mengolah sampah untuk menghasilkan barang yang lebih berguna. Untuk sampah organik pendekatan teknologi yang saat ini dailakukan oleh banyak orang adalah dengan mengubah sampah menjadi bahan bakar padat (briket) dan bahan bakar gas atau sampah diubah menjadi pupuk dengan komposter. komposter adalah alat yang terbuat dari drum plastik dengan menambahkan pipa pralon di dalamnya yang berfungsi sebagai saringan, dan menambah corong udara di atas drum untuk sirkulasi udara. Kemudian pada bagian bawah drum atau bak tersebut dilubangi untuk pengambilan pupuk organik yang siap panen. Masalah sampah juga dialami Dusun Susukan, Kelurahan Susukan , Kecamatan Susukan ,Kabupaten Semarang. Dusun susukan sebagian besar wilayahnya adalah ladang yang sebagian besar digunakan untuk bercocok tanam. Pengelolaan sampah di dusun Susukan yang kurang memadai ( pembuangan sampah yang tidak terkontrol ) menyebabkan sebagian warga masih membuang sampah disembarang tempat atau hanya membuat kubangan untuk pembuangan sampah. Hal ini mendatangkan Potensi bahaya bagi kesehatan sebagai berikut :

1. Penyakit diare, kolera, tifus menyebar dengan cepat karena virus yang berasal dari sampah dengan pengelolaan tidak tepat dapat bercampur air minum. Penyakit demam berdarah ( haemorhagic fever ) dapat juga meningkat dengan cepat di daerah yang pengelolaan sampahnya kurang memadai.

2. Penyakit jamur dapat juga menyebar ( misalnya jamur kulit ).

3. Penyakit yang dapat menyebar melalui rantai makanan. Salah satu contohnya adalah suatu penyakit yang dijangkitkan oleh cacing pita ( taenia ). Cacing ini sebelumnya masuk ke dalam pencernaan binatang ternak melalui makanannya yang berupa sisa makanan / sampah.

Dari survey yang dilakukan, beberapa permasalahan yang dapat didentifikasikan bahwa Dusun Susukan sudah memiliki mesin pencacah sampah yang dibeli oleh Pemerintah Desa Susukan tetapi mesin tidak digunakan sehingga dikhawatirkan akan rusak. Pembelian mesin tidak dapat merubah budaya dan cara penangan terhadap sampah hal ini dapat dilihat adanya fakta sebagai berikut:

1. Warga masih membuang sampah rumah tangga dengan sembarangan,sehingga akan setiap saat akan muncul masalah dimana pada musim penghujan akan menimbulkan bau yang tidak sedap, karena sampah tidak bisa kering sehingga tidak bisa dibakar., sedang saat kemarau penanganan karena banyak warga yang membakar sampah. Budaya ini disebabkan karena belum tersedianya Tempat Pembuangan Akhir (TPA) di Dusun Susukan.

2. Jika dihitung potensi sampah sangat besar yaitu sekitar $5 \mathrm{~kg} / \mathrm{hari.KK}$ belum dlihat oleh warga sebagai peluang untuk dijadikan usaha yang untuk menambah pemasukan kelompok masyarakat maupun keluarga.

Persoalan di atas membutuhkan solusi berupa pengolahan sampah rumah tangga menjadi kompos dan pupuk cair yang bisa digunakan untuk bercocok tanam dan optimalisasi mesin pencacah agar bisa digunakan untuk meningkatkan produksi

\section{METODE}

Tahapan Kegiatan yang telah dilakukan dapat dilihat pada gambar 1 . Secara detail pelaksanaan kegiatan dapat diterangkan sebagai berikut;

1. Sosialisasi kepada Pemangku Mitra Sosialisasi dilakukan sebagai langkah awal untuk pelaksanaan kegiatan. Sosialisasi dilakukan pada hari Selasa 
tanggal 5 Mei 2015 bertempat di rumah Bapak Kepala Dusun.

2. Pembentukan tim Pengelola kegiatan di tingkat Mitra

Kegiatan ini berupa rapat perwakilan warga untuk membentuk tim pengelola dan dilaksanakan pada hari Jumat, 8 Mei 2015.

3 Koordinasi Persiapan pembuatan bak sampah.

Kegiatan ini berupa pertemuan antara pelaksana dengan mitra yang membahas tentang rencana kegiatan tahap pertama yaitu pembuatan tong sampah. Materi yang dibicarakan meliputi pemetaan kebutuhan tong sampah, anggaran dan pelaksanaan.
Kegiatan ini terlaksana pada hari senin tanggal 18 Juni 2015.

4. Pembuatan dan pemasangan tong sampah.

Pekerjaan ini dilakukan oleh kelompok pengelola mitra di bawah supervisi tim. Kegiatan berlangsung antara tanggal 27 Juni sampai 19 Agustus 2015.

5. Pembuatan contoh komposter oleh pelaksana

Pelaksana membuat contoh komposter untuk bahan pelatihan ke tim pengelola dan ke mitra dilakukan di Laboratorium Teknik Mesin

6. Pelatihan pembuatan komposter dan Pengoperasian Komposter oleh pelaksana ke tim pengelola. 


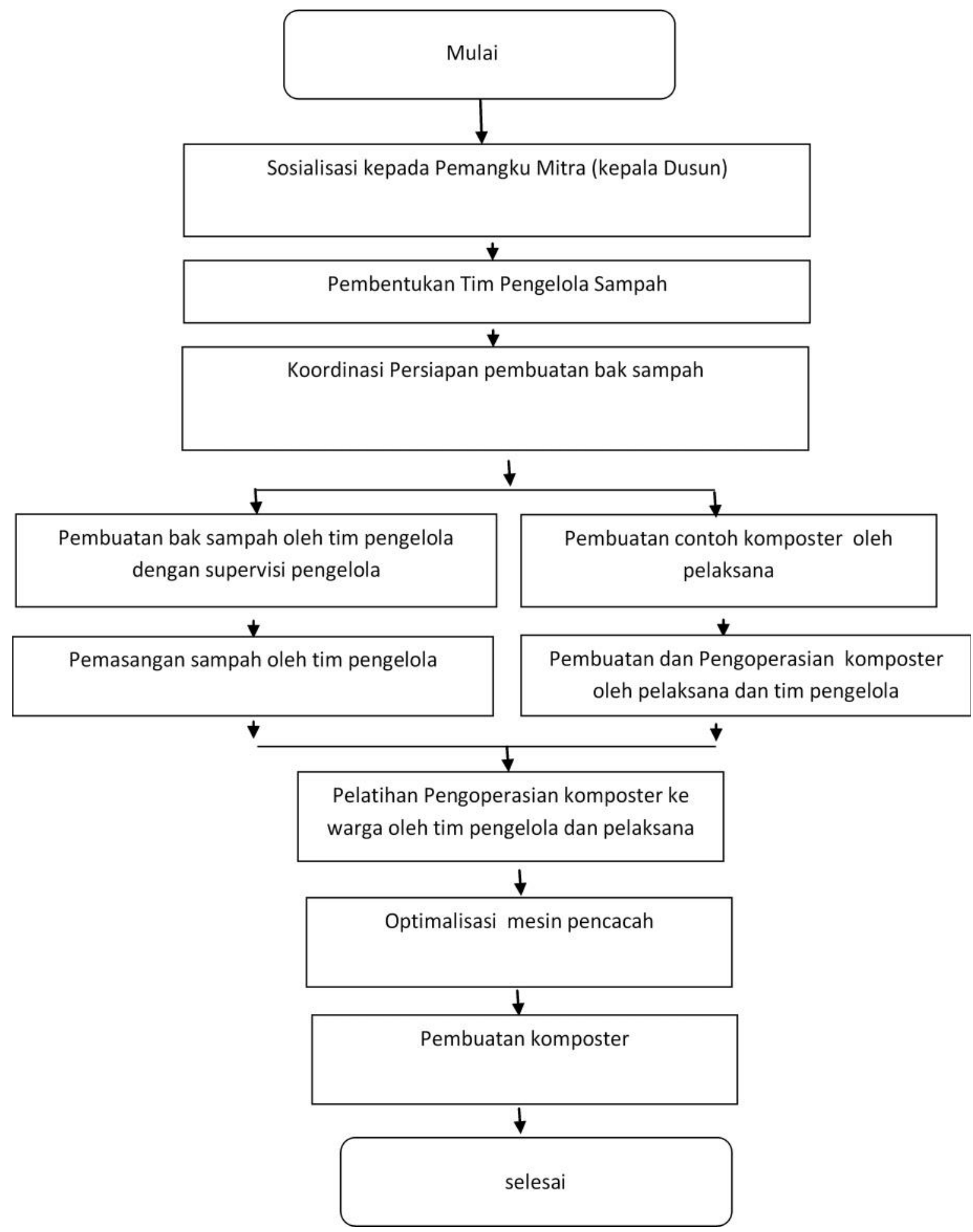

Gambar 1 Tahapan Kegiatan

Kegiatan ini bertujuan memberi bekal kepada tim pengelola untuk membuat komposter dan cara pengoperasiannya. Kegiatan ini terlaksana pada tanggal 21 Agustus 2015. 
6. Pelatihan Pengoperasian komposter ke warga oleh tim pengelola dan pelaksana. Pelaksana dan tim pengelola mengundang warga untuk memberi penyuluhan, pengarahan dan pelatihan pengoperasian komposter. Kegiatan ini terlaksana pada tanggal 1 November 2015. Pembuatan komposter oleh tim pengelola untuk warga

6. Tim pengelola dan pelaksana membuat komposter untuk warga masing-masingmasing rumah dibuatkan 1 komposter.

\section{HASIL DAN PEMBAHASAN}

\section{Tim Pengelola}

Tim pengelola terbentuk berdasarkan aspirasi warga dimana tim pengelola diambil dari pengurus di RT 03 dan RT 04. Tim Pengelola bekerja di bawah koordinasi Ketua dusun merupakan mitra langsung dari pelaksana. Dalam pelaksanaan di lapangan kepala dusun dibantu oleh ketua RT 03 dan RW 04 mengkoordinasi kegiatan tim pengelola meliputi pembelanjaan material pembuatan tong sampah dan komposter, pembuatan tong sampah dan pemasangannya dan pembuatan komposter, pengoperasian sampel komposter dan mengoordinir aktivitas setelah kegiatan berakhir. Secara umum tim pengelola bekerja dengan baik dan sangat antusias menjalankan aktivitasnya.

2. Pembuatan Bak Sampah dan Pemasangan Bak Sampah di titik strategis. .

Pemasangan tong sampah di titik strategis ini bertujuan sebagai bak pemisah sampah. Sampah rumah tangga yang dulu dibuang di sembarang tempat diubah ditampung di bak sampah yang diletakkan di titik-titik strategis. Bak sampah ini hanya menampung sampah anorganik sedangkan sampah organik dipisahkan dan di olah dikomposter.

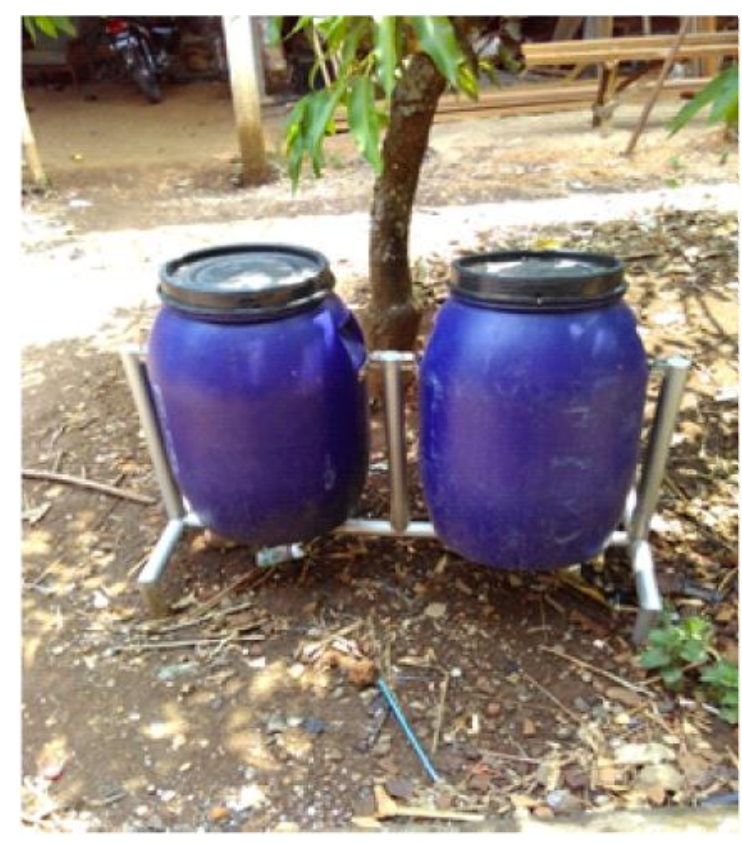

Gambar 3 Bak sampah anorganik

Gambar 3 menunjukkan gambar tong sampah yang telah terpasang. Tong sampah ini taerpasang di 12 (dua belas) titik dengan asumsi setiap tong sampah digunakan 6-7 kepala keluarga. Dengan adanya bak sampah ini perlahan-lahan budaya masyarakat yang membuang sampah disembarang tempat bisa diubah dengan membuangnya di tempat sampah.

\section{Pengelolaan Sampah Organik dengan Komposter}

Secara umum pemanfaatan sampah organik untuk bahan yang lebih terpakai ada dua cara yaitu diolah menjadi bahan bakar atau sumber energi dan diolah menjadi pupuk. Untuk program ini sampah dimanfaatkan untuk pupuk mengingat daerah sasaran sebagian besar adalah daerah pertanian. Proses Pengolahan sampah menjadi pupuk dilakukan dengan alat yang 
namanya kompostor. Kompostor yang disiapkan oelh pelaksana ada dua macam yaitu komposter yang menghasilkan bahan kompos padat dan bahan penghasil pupuk cair.
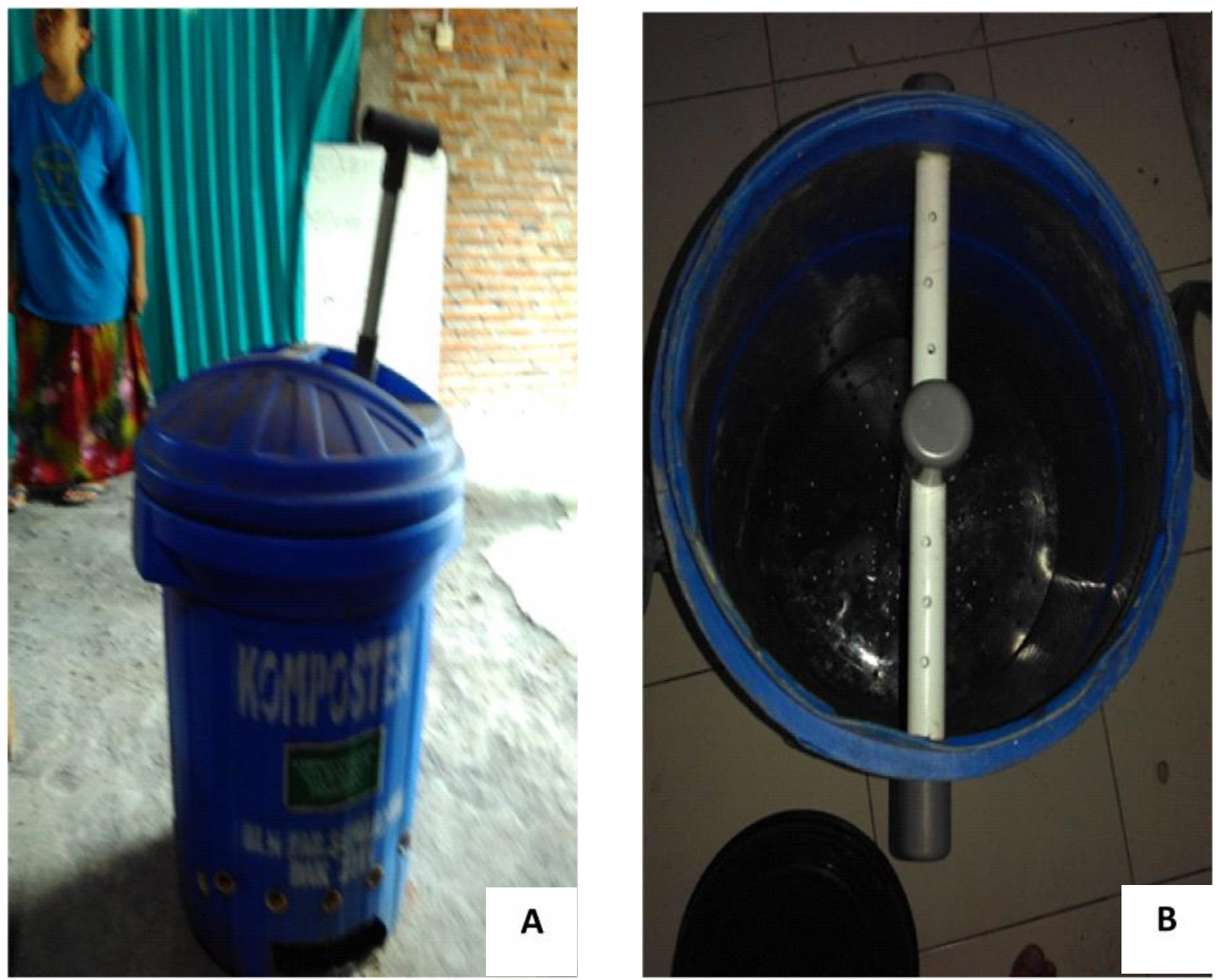

Gambar 3. Komposter Penghasil pupuk padat

\section{A. Untuk padat B. Untuk Cair}

Pelaksana pada awalnya membuat contoh komposter untuk penghasil kompos sebagaimana diperlihatkan pada gambar 4. Bahan komposter terbuat dari plastik yang bagian samping bawah dilubangi dan dipasang pipa pvc, sedangkan bagian bawah diberi mesh wire untuk penyangga sampah. Pengoperasian kompester telah dilakukan oleh tim pengelola di bawah bimbingan tim pelaksana dengan memasukkan sampah kemudian di siram dengan bahan activator. Activator yang digunakan adalah pupuk cair yang diperoleh di toko pertanian dimana pupuk EM-4 campur dengan air dengan perbandingan 1 liter pupuk : 50 liter air. Proses selanjutnya komposter di tutup dan ditunggu hasilnya. Tim pelaksana juga membuat contoh komposter penghasil pupuk cair sebagaimana dalam gambar 3 B. Komposter ini terbuat dari tabung plastik dilengkapi dengan pipa pvc yang dilubangi dan dilengkapi dengan pipa plastik untuk mengeluarkan cairan pupuk dari dalam komposter. Hasil dari komposter penghasil kompos padat 
dapat dilihat pada gambar 4. Setelah komposter menghasilkan kompos, pelaksana dan tim bersepakat untuk melakukan sosialisasi dan pelatihan ke warga mengenai penanganan sampah organik. Dalam sosialisasi yang diikuti oleh ibu-ibu warga RT 03 dan sebagian RT 04 peserta sangat antusias dan segera ingin mencoba komposter.

\section{Optimalisasi Mesin Pencacah.}

Evaluasi yang dilakukan terhadap pengoperasian komposter menunjukkan bahwa sampah dengan ukuran yang besar akan membutuhkan waktu yang lama sedangkan pada kenyataannya di dusun susukan sudah tersedia mesin pencach namun kondisinya rusak dan mesin penggeraknya hilang. Untuk menunjang efektifitas kegiatan pengelolaan maka diputuskan mesin pencacah dioptimalkan kembali dengan mengadakan perbaikan dan pembeliaan mesin diesel baru. Ini diperlukan apabila tim pengelola nanti ingin memproduksi kompos yang dipasarkan keluar dengan bahan baku daun-daunan yang banyak tersedia di daeraha sekitar tempat tinggalnya.

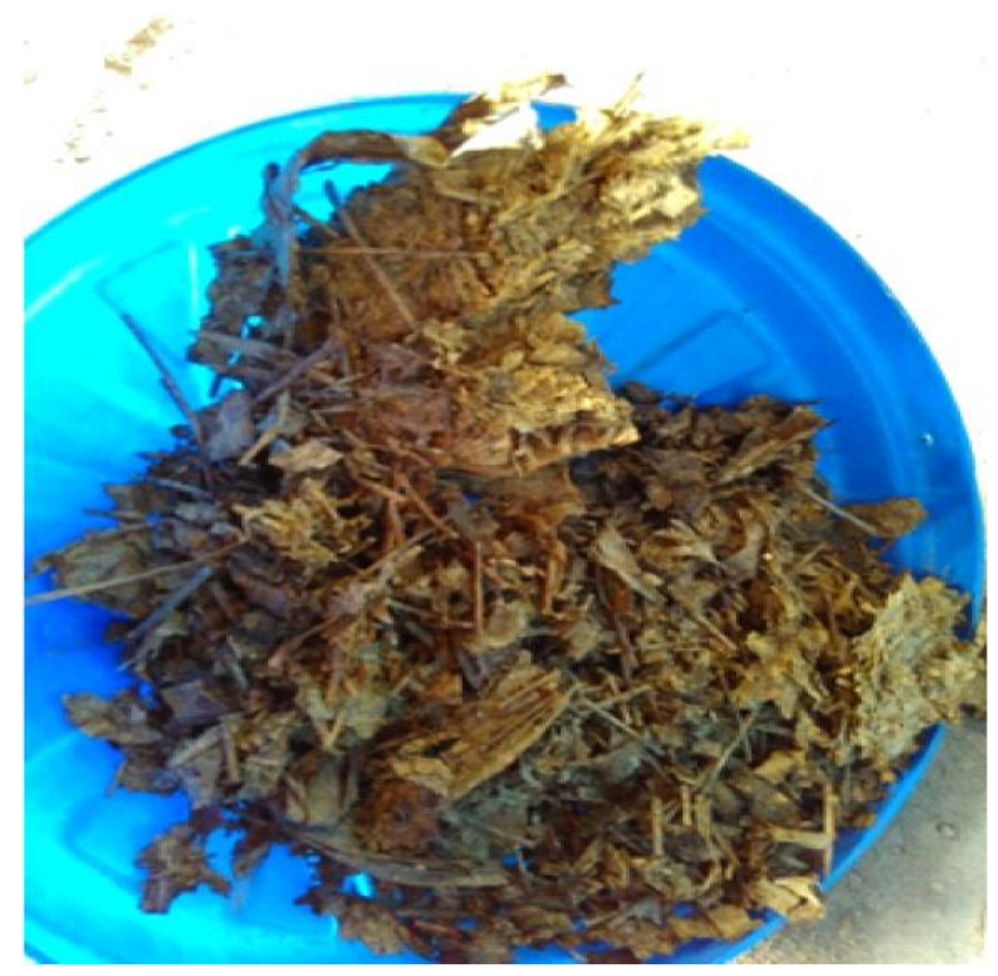

Gambar 4 . Kompos

Secara umum semua aktifitas dapat berjalan dengan baik. Dari pelatihan yang diadakan masyarakat semakin mengerti bahaya sampah jika tidak dikelola dengan baik. Pengetahuan tersebut Selanjutnya berdampak pada budaya pengelolaan sampah yang awalnya dibuang disembarang tempat sekarang berubah. Sampah dipisahkan terlebih dahulu antara sampah organik dan anorganik dan sampah organik diolah di komposter dan akan menghasilkan pupuk kompos. iTanggapan masyarakat sasaran terhadap kegiatan ini sangat baik. Sebagaimana dijelaskan dalam bagian Tim Pengelola tim pengelola bekerja dengan semangat dan antusias melaksnakan program ini. 
Antusias warga juga tampak saat mengikuti pelatihan dan sosialisasi pengoperasian komposter. Pelaksana pada akhir kegiatan mengirimkan kuosenier yang diisi oleh kepala dusun dan ketua RT 03 dan RT 04. Ketiga responden menyatakan bahwa kegiatan ini bermanfaat bagi pribadi maupun bagi lingkungan. Dengan adanya program ini menggerakkan warga untuk hidup lebih sehat bisa lebih mudah karena ketersediaan fasilitas pembuangan sampah sehingga lingkungan akan lebih bersih. Pimpinan warga ini juga berkomitmen untuk melanjutkan kegiatan ini dan dijadikan agenda kegiatan RT. Warga juga berharap bimbingan akan terus berlanjut bahkan kegiatan kalau dimungkinkan dilakukan di sektor-sektor yang lain, misalkan sektor pengembangan industri rumah tangga untuk meningkatkan ekonomi warga.

\section{SIMPULAN DAN SARAN}

\section{Simpulan}

Kegiatan penanganan sampah di Dusun Susukan kecamatan Susukan Kabupaten Semarang telah terlaksana dengan indikator sebagai berikut;

a. Terbentuknya tim pengelola sampah untuk mengelola sampah tingkat RT.

b. Warga memiliki metode dan ketersedian sarana untuk mengelola sampah yaitu dengan menggunakan bak pengumpul sampah anorganik dan komposter untuk sampah organik.

c. Optimalisasi mesin pencacah diperlukan untuk mendukung program pembuatan kompos seehingga bisa menjadi alternatif usaha tingkat dusun.

\section{Saran}

a. Untuk memastikan bahwa alat akan berhasil warga membutuhkan bukti terlebih dahulu sehingga ke depan sosialisasi dan penunjukkan bukti bahwa alat memang dapat bekerja sesuai yang disampaikan harus dilakukan di awal kegiatan.

b. Penangan sampah bisa dilanjutkan dengan penanganan sampah anorganik contohnya dengan program penangan sampah plastik dengan mesin pengolah sampah, penangan sampah kaleng untuk kerajinan dan lain sebagainya.

\section{PERSANTUNAN}

Kami ucapkan terima kasih kepada Kementerian Riset, Teknologi dan Pendidikan Tinggi yang telah membiayai pelaksanaan Kegiatan Pengabdian Masyarakat melalui skim IbM tahun anggaran 2015.

\section{DAFTAR PUSAKA}

Basriyanto, "Memanen Sampah", Kanisius,.

."Fisika Startrek", Kepustakaan Populer Gramedia, Sofian, "Sukses Membuat Kompos dari Sampah”, AgroMedia, 9790060165, 9789790060166.

Singgih Sastradiharja, "Menanam buah organik", Ganeca Exact,

HR. Sudrajat, "Mengelola Sampah Kota", Niaga Swadaya,

Setyo Purwendro, "Mengolah Sampah u/ Pupuk \& Pestisida”, Niaga Swadaya, 
Moch Nurhasim, Pusat Penelitian Politik (Indonesia), "Studi kebijakan pertahanan: evaluasi pelaksanaan darurat militer dan sipil di Aceh, 2003-2005 : fokus, evaluasi pelaksanaan darurat militer di Aceh, 2003-2004”, TransMedia, 2006,

Willyan Djaja, "Langkah Jitu Membuat Kompos dari Kotoran Ternak \& Sampah”, AgroMedia, Murbandono HS, "Membuat Kompos (Baru)", Niaga Swadaya

Teti Suryati, "Bijak dan Cerdas Mengolah Sampah", AgroMedia, http://dc403.4shared.com/doc/Tfo3GJbZ/preview.html 